\title{
Correction to: The Gonadotropin-Releasing Hormone Analogue Therapy May Not Impact Final Height in Precocious Puberty of Girls With Onset of Puberty Aged 6 - 8 Years
}

\author{
Ozlem Korkmaz ${ }^{\mathrm{a}, \mathrm{c}}$, Gulsenem Sarib, Ilkin Mecidova, Samim Ozenª, \\ Damla Goksen ${ }^{\mathrm{a}}$, Sukran Darcan ${ }^{\mathrm{a}}$
}

This is to correct the published article, Journal of Clinical Medicine Research, 2019;11(2):133-136. DOI: 10.14740/ jocmr3710.

The authors would like to make the corrections as follows.

In abstract section, paragraph 3, change "Fourteen cases received monthly $3.75 \mathrm{mg}$ depot triptorelin acetate and 11 received three-monthly $11.25 \mathrm{mg}$ depot" to "Fourteen cases received monthly $3.75 \mathrm{mg}$ depot triptorelin acetate and $11 \mathrm{re}$ ceived three-monthly $11.25 \mathrm{mg}$ depot leuprolide acetate."

In materials and methods section, paragraph 2 , change "Fourteen of the treated cases received monthly $3.75 \mathrm{mg}$ depot triptorelin acetate $75-100 \mu \mathrm{g} / \mathrm{kg}$, while 11 received three monthly $11.25 \mathrm{mg}$ depot triptorelin acetate" to "Fourteen of the treated cases received monthly $3.75 \mathrm{mg}$ depot triptorelin acetate $75-100 \mu \mathrm{g} / \mathrm{kg}$, while 11 received three monthly 11.25 mg depot leuprolide acetate."

In results section, paragraph 1 , change "Patients of the treatment group received two different treatment regimens including 14 cases (56\%) who received monthly $3.75 \mathrm{mg}$ triptorelin acetate $75-100 \mu \mathrm{g} / \mathrm{kg}$ and 11 cases (44\%) who received three-monthly $11.25 \mathrm{mg}$ depot triptorelin acetate" to "Patients of the treatment group received two different treatment regimens including 14 cases $(56 \%)$ who received monthly $3.75 \mathrm{mg}$ triptorelin acetate $75-100 \mu \mathrm{g} / \mathrm{kg}$ and 11 cases (44\%) who received three-monthly $11.25 \mathrm{mg}$ depot leuprolide acetate."

In results section, paragraph 6, change "No difference was determined in terms of initial height SDS, bone age, length of treatment, final height SDS or BMI SDS values between groups receiving monthly $3.75 \mathrm{mg}$ triptorelin acetate or threemonthly $11.25 \mathrm{mg}$ depot triptorelin acetate treatment $(\mathrm{P}>$ $0.05)$ " to "No difference was determined in terms of initial height SDS, bone age, length of treatment, final height SDS or BMI SDS values between groups receiving monthly $3.75 \mathrm{mg}$ triptorelin acetate or three-monthly $11.25 \mathrm{mg}$ depot leuprolide acetate treatment $(\mathrm{P}>0.05)$."

Manuscript submitted April 22, 2019, accepted April 25, 2019

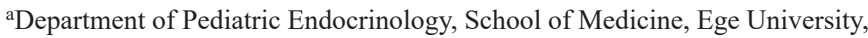
Izmir, Turkey

${ }^{b}$ Department of Pediatrics, School of Medicine, Ege University, Izmir, Turkey ${ }^{\mathrm{c} C}$ Corresponding Author: Ozlem Korkmaz, Department of Pediatric Endocrinology, School of Medicine, Ege University, Bornova 35100, Izmir, Turkey. Email : ozlem-korkmazz@hotmail.com 